This is the peer-reviewed author's accepted manuscript of:

Lugli F., Cipriani A., Capecchi G., Ricci S., Boschin F., Boscato P., lacumin P., Badino F., Mannino M.A., Talamo S., Richards M.P., Benazzi S., Ronchitelli A., Strontium and stable isotope evidence of human mobility strategies across the Last Glacial Maximum in southern Italy, Nature Ecology \& Evolution (2019)

The final published version is available online at:

https://doi.org/10.1038/s41559-019-0900-8

https://www.nature.com/articles/s41559-019-0900-8

This version is subjected to Nature terms for reuse that can be found at: http://www.nature.com/authors/policies/license.html\#terms 


\section{Strontium and stable isotope evidence of human mobility strategies across the Last Glacial Maximum in southern Italy}

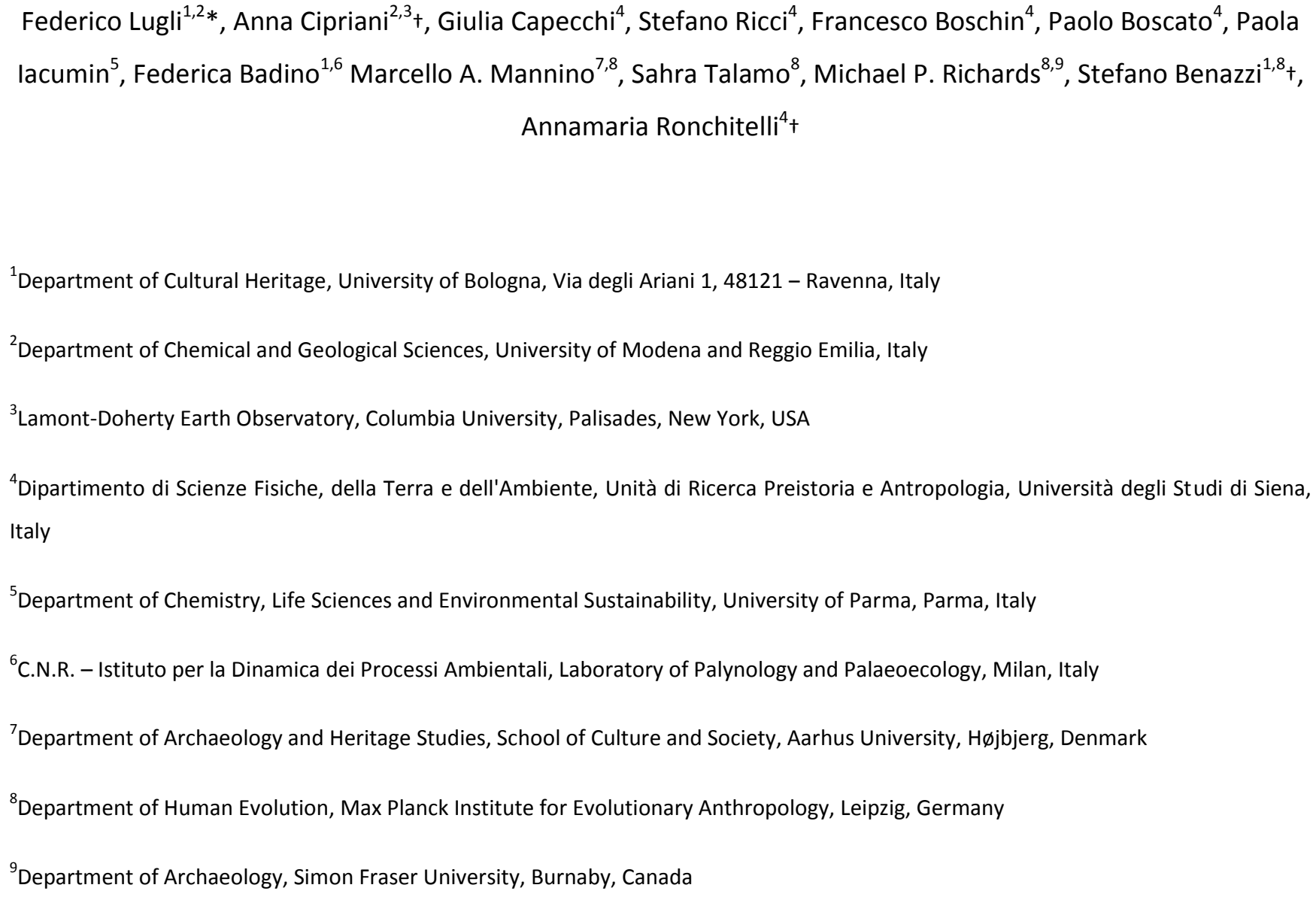

Keywords: strontium isotopes; Gravettian; Last Glacial Maximum; Grotta Paglicci; human mobility 


\begin{abstract}
Understanding the reason(s) behind changes of human mobility strategies through space and time is a major challenge in paleoanthropology. Most of the time this is due to the lack of suitable temporal sequences of human skeletal specimens during critical climatic or cultural shifts. Here, we present temporal variations in the $\mathrm{Sr}$ isotope composition of 14 human deciduous teeth and the $\mathrm{N}$ and $\mathrm{C}$ stable isotope ratios of 4 human remains from the Grotta Paglicci site (Apulia, Southern Italy). The specimens were recovered from the Gravettian and Epigravettian layers, across the Last Glacial Maximum, and dated between 31210-33103 and 18334-19869 cal

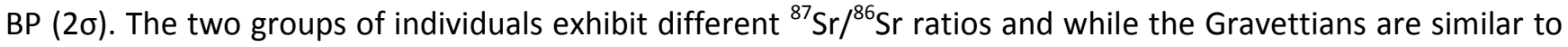
the local macrofauna in terms of $\mathrm{Sr}$ isotopic signal, the Epigravettians are shifted towards higher radiogenic $\mathrm{Sr}$ ratios. These data, together with stable isotopes, can be explained by the adoption of different mobility strategies between the two groups with the Gravettians exploiting logistical mobility strategies and the Epigravettian applying residential mobility.
\end{abstract}


People have moved across the landscape since the rise of human species, primarily in search of food (1), but also forced by natural disasters (2), environmental changes (3-6), human conflicts (7) or more simply in search of better fortune (8). Undoubtedly, climate change is one of the main reasons behind big-scale human mobility $(9,10)$. Small-scale human mobility strategies instead are related to a mix of different biological and cultural factors that span from the spatial dispersion of local resources (8) to population dynamics (5). Because moving is bioenergetically expensive, human group reduce their mobility to a minimum threshold by natural selection, with progressively shorter distances and fewer residential moves per year (11). In this sense, the reconstruction of hunter-gatherer mobility patterns is a key point to understand how human activities have been influenced by climate and, in general, to gain insight into human mental flexibility during recent evolution.

Two different models describe mobility strategies of modern hunter-gatherer groups in terms of foodconsumer relationship (12). According to Binford (12), foragers usually do not store food, practicing frequent residential moves from their base camp to the food-resource locus. Collectors, instead, store food and move to key food-sites with frequent and targeted logistical forays of few individuals.

A crucial period in terms of both human mobility and climatic changes is represented by the transition from the Gravettian to the later technocomplexes, during the Upper Palaeolithic (UP). The Gravettians spread to most of Europe between $\sim 30,000$ and $\sim 20,000$ years ago and disappeared across the Last Glacial Maximum (LGM), replaced by other complexes, e.g. the Italian Epigravettian and the French Iberian Solutrean. Yet, the relationship between the Gravettian and later technocomplexes is unclear (13 and references therein). Recent aDNA analyses associate Epigravettians with the Villabruna genetic Cluster. The latter has affinities with the Near East peoples, suggesting that Gravettians were rapidly substituted by groups migrating from southeastern European/west Asia refugia after the LGM peak (14).

So far most of the research about UP human mobility has focused on indirect evidence such as raw material procurement (e.g. 15-18), lower limb morphology (e.g. 19-22) and zooarchaeological interpretations (e.g. $23,24)$. What emerges from these studies is that Gravettian groups relied on large territories, covered by longdistance logistical forays, and based their subsistence on a great variety of food resources on a seasonal basis (16). Skeletal evidences from limbs seem to indicate the existence within Gravettian groups of a clear division of labor between male and female (20-21) and a high degree of mobility, which decreased during the onset of the $\operatorname{LGM}(19,22)$.

In the last two decades, human provenance and mobility studies have benefited from the use of isotopic tracers and the application of the micro-destructive LA-MC-ICP-MS technique (26-30). This is particularly true 
for the ${ }^{87} \mathrm{Sr} /{ }^{86} \mathrm{Sr}$ ratio of dental remains, thanks to the robust relationship of the dental $\mathrm{Sr}$ isotope fingerprint with the geographical provenance of the individual (see 25).

In this paper, we use $\mathrm{Sr}$ isotopes of human remains to assess potential differences in human mobility patterns between Gravettians and Epigravettians from Grotta Paglicci (Rignano Garganico, Apulia, Southern Italy). The stratigraphy of the site, located at the foothills of the Gargano promontory, has yielded more than 140 human remains, spanning from the Early Gravettian to the Final Epigravettian period, attesting for a frequent human use of the area $(31,32)$.

Acting as a sort of climate refugium (e.g. 32,33), Paglicci can be considered an ideal base-camp for huntergatherer groups. We, therefore, analyzed the $\mathrm{Sr}$ isotopes of fourteen human deciduous teeth, recovered from the Gravettian (eleven teeth) and the Epigravettian (three teeth) layers of the site, dated between 31210-

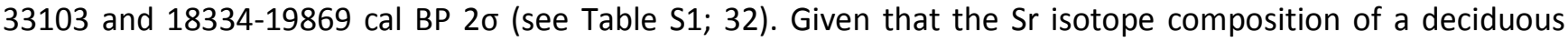
tooth reflects that one of the mother of the individual (see Fig. S1, 30), we investigated the mobility of the human groups and ultimately the role of women within social dynamics. Moreover, we explored their eating habits with the $\delta^{13} \mathrm{C}$ and $\delta^{15} \mathrm{~N}$ of human bone collagen and discussed human behavior and hunting choices across the LGM in Southern Italy.

\section{Results}

\section{Sr isotopes}

The local baseline of Grotta Paglicci was determined through the analysis of modern plants and rodent teeth. Tooth enamel of several macro-mammals was also analysed for comparison. Considering all the local proxies, an interval between 0.7080 and 0.7088 can be conservatively considered as the broadest and most likely local

$\mathrm{Sr}$ isotope range. Macro-mammals exhibit the lowest ${ }^{87} \mathrm{Sr} /{ }^{86} \mathrm{Sr}$ ratios during the Early Gravettian $(\sim 0.7081)$ (Table 1).

In situ laser ablation ${ }^{87} \mathrm{Sr} /{ }^{86} \mathrm{Sr}$ ratios of 61 enamel micro-samples of 14 human teeth vary between 0.70738 and 0.70952. Considering the average value of each tooth, the ${ }^{87} \mathrm{Sr} /{ }^{86} \mathrm{Sr}$ ratios span from 0.70800 to 0.70930 (mean: $0.70861 \pm 0.00087,2 \sigma ; n=14)$. A statistical significant difference is observed when human isotope data are compared in terms of archaeological period (one-way ANOVA $n=61 ; F=20.3 ; p<0.00001$; Epigravettian: $0.70926 \pm 0.00031$; Final Gravettian: $0.70890 \pm 0.00066$; Evolved Gravettian: $0.70847 \pm 0.00085$; Early Gravettian: $0.70808 \pm 0.00078$; Fig. S5), with the Epigravettians characterized by the highest radiogenic values 
and the Early Gravettians by the lowest (Table 2). In terms of temporal evolution, the human Sr isotopes increases with time, from the Early Gravettian to the Epigravettian (Fig. 3). The more radiogenic ${ }^{87} \mathrm{Sr} /{ }^{86} \mathrm{Sr}$ ratios of the Epigravettian humans, however, are not paralleled by their respective contemporary fauna, which, instead, displays the same values of the late stage of the Gravettian period.

When taking into account the average ${ }^{87} \mathrm{Sr} /{ }^{86} \mathrm{Sr}$ ratio of each tooth, all but one Gravettian specimen (PA91 ${ }^{87} \mathrm{Sr} /{ }^{86} \mathrm{Sr}=0.70900$; Final Gravettian) fit the local bioavailable $\mathrm{Sr}$ isotope baseline, whilst the three Epigravettians exhibit a likely non-local signal (Epigravettians vs. rodent teeth; two-tailed Mann-Whitney Utest; $p<0.001)$.

In terms of intra-tooth variability, expressed as 2-standard deviations, the Gravettian teeth are very different from the Epigravettian teeth. In general, Epigravettians show a limited intra-tooth variation (from 0.00028 to 0.00041), whilst the largest intra-tooth variations are observed for Gravettians (from 0.00027 to 0.00111 ). Of the three Gravettian teeth with likely non-local Sr isotope ratios (single LA values), two specimens (PA91 and PA94) show an increase of the ${ }^{87} \mathrm{Sr} /{ }^{86} \mathrm{Sr}$ ratio from the tooth apex to the cervix, with the higher radiogenic values nearby the cervix; the third tooth (PA93) shows a change in the opposite direction. Despite these fluctuations, all the Gravettian teeth possess at least one ${ }^{87} \mathrm{Sr} /{ }^{86} \mathrm{Sr}$ ratio compatible with the local baseline.

\section{Stable isotopes of bone collagen}

Gravettian human remains, Paglicci 12 and Paglicci 25 , have $\delta^{13} \mathrm{C}$ values of -18.8 and $-18.4 \%$ and $\delta^{15} \mathrm{~N}$ values of 13.9 and $13 \%$ respectively.

The $\delta^{13} \mathrm{C}$ values of the collagen extracted from Epigravettian human remains are $-19.4 \%$ for PA85 (layer 10-14) and $-18.6 \%$ for PA89 (layer 16b); while the $\delta^{15} \mathrm{~N}$ values are $11 \%$ for PA 85 and $14 \%$ o for PA89.

We have used the data generated by lacumin et al. (34) on non-ultrafiltered 'collagen' as a baseline for interpreting the $\delta^{15} \mathrm{~N}$ and $\delta^{13} \mathrm{C}$ values of the humans from Grotta Paglicci (Fig. 4). The Gravettian humans Paglicci 12 and Paglicci 25 have higher $\delta^{13} \mathrm{C}$ values (respectively by $1.4-2.1 \%$ and $1.8-2.5 \%$ ) and $\delta^{15} \mathrm{~N}$ values (respectively by 6.0-7.4\% and 5.1-6.5\%o) than the mean isotopic ratios for the three terrestrial herbivore species (34). For the Epigravettian humans, PA85 shows a $\delta^{15} \mathrm{~N}$ value $4.5 \%$ o higher than Cervus elaphus, 3.1\%。 higher than Bos primigenius and 4.2\% higher than Equus ferus; PA89 retains a $\delta^{15} \mathrm{~N}$ value $7.5 \%$ o higher than Cervus elaphus, 6.1\%o higher than Bos primigenius and 7.2\%o higher than Equus ferus (34).

\section{Discussion}




\section{Gravettian}

The average Sr isotope ratios of all Gravettian teeth, except one (PA91, Final Gravettian) are consistent with the local isotope baseline $(0.7080-0.7088)$. This can simply suggest that the mothers (see Fig. S1, 30) of these individuals spent most of their pregnancy/breastfeeding period at Grotta Paglicci or at a place with a similar local isotope ratio. Conversely, specimen PA91 displays an average ${ }^{87} \mathrm{Sr} /{ }^{86} \mathrm{Sr}$ ratio slightly more radiogenic (0.70900) than the local baseline. In this case, the woman might have spent part of the pregnancy/breastfeeding in a different place or consuming non-local food.

When looking at intra tooth variability, the Gravettian teeth present a very large variability compared to the Epigravettian teeth. Intra-tooth variations may be indicative of the adopted mobility strategies, where a larger isotopic range could be explained by a broader exploitation of patchy distributed resources, while a limited intra-tooth range could be interpreted as a narrower territorial use or the use of resources from an area with the same local geology. In this sense, we suggest that the larger intra-tooth range observed for some Gravettian individuals, may result from sub-annual movements between at least two geologically different places.

The exact source of the Gravettian non-local signals is hard to pin down. Modern plant specimens around the site (up to a $20 \mathrm{~km}$ radius) do not have $\mathrm{Sr}$ isotope ratios higher than $\sim 0.709$ or as low as $\sim 0.707$ (Fig. 1). In terms of isotope variability, Southern Italy exhibits a narrow ${ }^{87} \mathrm{Sr} /{ }^{86} \mathrm{Sr}$ range $(\sim 0.707-\sim 0.709 ; 35-37)$ because it is mostly dominated by recent limestones ranging in age from the Pliocene to the Quaternary. In this area, isotopic values higher than modern seawater ( 0.7092) are scarcely documented and restricted to specific geological areas that include the volcanic area of Roccamonfina and the Hercynian basement outcrops of Calabria and of the easternmost portion of Sicily $\left({ }^{87} \mathrm{Sr} /{ }^{86} \mathrm{Sr}\right.$ ratios up to $\left.\sim 0.71 ; 36,37\right)$. Instead, low $\mathrm{Sr}$ isotope ratios are common among Campanian, Aeolian and Etna volcanoes (38), and along the Salentine coast $(39,40)$. Therefore, the higher and lower Sr isotope ratios endmembers found in the Gravettian teeth could derive from the exploitation of resources as far south as e.g. Calabria. Given that values between 0.709 and 0.71 are quite common in other areas of Europe, we cannot precisely identify possible origins from outside Italy. However, archaeological evidences (Final Epigravettian) indicate the presence in Dalmatia (Kopačina Cave) of raw materials from the Gargano area (41), likely suggesting the possibility of exchanges/contacts with groups from the Balkans.

A more conservative and alternative explanation for Gravettian human $\mathrm{Sr}$ isotopes shifted toward modern seawater ( 0.7092) may be the heavy reliance on marine food $(42,43)$ and, therefore, travels towards the Adriatic shore, about $100 \mathrm{~km}$ away at the time. 
Taken together, the average local signals registered within Gravettian teeth and the high intra-tooth variability observed for some of them point towards a mobility pattern akin to modern collectors, hence characterized by infrequent base-camp moves and focused logistical forays to gather patchy distributed resources. These mobility strategies are in agreement with the local climatic conditions. As recently suggested by the analysis of the micro-fauna from Grotta Paglicci, the climate during the Gravettian was characterized by mean temperatures $\sim 5^{\circ} \mathrm{C}$ lower than present-day and by open environments with dry meadows (32). The coldest conditions, likely correlated to the LGM peak, are found at the end of the Evolved Gravettian (around level 20e). Samples from this time span are characterized by the highest isotopic intra-tooth variability, suggesting long logistical travels within a period of ca. 1 year. Ethnographic studies indicate that, in cold environments, modern hunters-gatherers tend to reduce at a minimum the residential high-energetically demanding moves, but they exploit targeted forays to collect distant resources (e.g. up to $70 \mathrm{~km}$ for the Nunamiut; 44). In addition, recent studies on the territorial size of Gravettian groups from Tuscany (Italy) support the hypothesis of a likely large use of the landscape (almost the entire Tuscany), with long seasonal logistic travels (16). Long targeted forays of the Grotta Paglicci Gravettian humans are also testified by the presence of ornamental sea shells from one of the buried individuals (Paglicci 25: level 21b; 31) and by the presence of marine gastropods along the archaeological sequence, which suggests that Gravettians walked at least $~ 100 \mathrm{~km}$ to gather shells from the Adriatic shore.

Yet, these movements find no evidence within the macro-fauna isotopic record. However, the homogeneous geology of Central Italian bedrock (limestones dating between Jurassic and Holocene) can most likely mask high-mobility patterns of fauna (35).

From our Sr data, we can cautiously speculate that humans from Grotta Paglicci in the Gravettian exploited local fauna, at least seasonally, perhaps following the annual movements of ungulates. This is evident especially during the Early Gravettian, when the Sr isotope ratios of both humans and animals tend to converge towards a common lower Sr ratio, with Equus ferus as the lowest and more likely isotopic end-member. This low ratio within the considered fauna is consistent with animal movements/migrations toward the southern portion of the Apulia region (40). Zooarchaeological and taphonomic evidences of the earliest stages of the Gravettian suggest also a strong reliance on ungulates from open habitats (45).

Stable isotopes of carbon and nitrogen support the idea of a high-protein diet for the two Gravettians buried individuals here studied (Paglicci 12 and Paglicci 25). Given that their isotope composition was enriched by more than one trophic step $\left(\delta^{13} \mathrm{C}=\sim 1.0 \%\right.$; $\delta^{15} \mathrm{~N}=3.0-5.0 \%$ o compared to some of their main terrestrial prey, these individuals likely relied on meat from large-sized mammals with the additional limited intake of a 
secondary protein source. $\delta^{13} \mathrm{C}$ values higher than $-18.8 \%$ ond $\delta^{15} \mathrm{~N}$ values higher than $13 \%$ ore compatible with the consumption of aquatic resources, as observed for other UP humans (e.g. 46-48), possibly exploited on a seasonal basis (Fig. 4). While fish remains are absent at Grotta Paglicci, bird bones with butchering marks are present within the Early Gravettian layers, hence indicating a possible minimal consumption of freshwater birds (49). Nevertheless, high protein diets may isotopically mask the intake of resources from low trophic levels, such as the use of plant foods. Recent residue analyses of a grinding tool from the Early Gravettian layer 23a of Grotta Paglicci support the processing and exploitation of flours by humans (50). Such a wide diet breadth, though largely based on fauna exploitation, is in agreement with the logistical mobility model we defined for the Gravettians of Grotta Paglicci based on Sr isotopes. In fact, modern hunter-gatherers, heavily reliant on faunal resources, may use a large territorial range during the year, but they do not necessarily practice as frequent residential moves as groups that are dependent on plant gathering (51). Within societies living in cold environments, men alone fulfill the dietary requirement of the group with large game. Women are generally taking care of children and/or foraging local plants, limited in terms of long-distance mobility by the burden of pregnancy (52). Hence, it is not unlikely that within Gravettian groups, labor tasks were divided between men and women (21-22) perhaps driven by seasons and dietary requirements of the entire group. Although not entirely supported by stable isotopes, the more radiogenic Sr values in some human enamel, not far from the modern seawater value ( 0.7092), may result from periodical travels to the seashore. The exploitation of mollusk as food by Late Pleistocene groups has been attested within other coastal regions of the Italian landscape e.g. Liguria (Riparo Mochi and Arene Candide; 53).

\section{Epigravettian}

$\mathrm{Sr}$ isotopes of human enamel indicate that Epigravettians from Grotta Paglicci based their subsistence mostly on non-local resources, being their isotope ratio more radiogenic than the local bioavailable Sr. Thus, as the deciduous teeth grew, the mothers of these individuals might have likely lived for 6-12 months in a place not identifiable with the surroundings of Grotta Paglicci. Moreover, the very limited intra-tooth variability of Epigravettian teeth (from 0.0003 to 0.0004 , see Fig. 2) suggests that during this period, the mothers did not move much, residing in the same place or moving across places with the same isotopic ratio (>0.709). Given that these teeth derive from different archaeological layers, their non-local isotopic ratio should reflect a sort of recurring mobility pattern, maybe constrained by seasons and consistent with the residential mobility model (12). According to this, modern foragers gather resources near the base-camp, but when resources begin to run out, the base-camp is moved. A diet including small mammals or plants, rather than large game, is also more 
likely in gathering economies, because foraging at short distances from the base-camp allows the use of lowreturn rate resources (51). However, during this period we have no evidences at Grotta Paglicci of a strong dependency on small mammals in terms of zooarchaeological record (45).

Lithic data from Apulia $(54,55)$ seem to suggest a change in terms of human mobility across the LGM. This has been interpreted to indicate the exploitation of logistical mobility by Epigravettian groups rather than residential $(54,55)$, in contrast to what we propose based on Sr isotopes. However, we stress that, while our human specimens are from the Early Epigravettian, the lithic assemblages from $(54,55)$ are much younger $(5-10$ ka). This might suggest a long-term adaptation of the Epigrattevians to the local environment and a consequent change of the mobility patterns.

Stable isotopes show that the diet of the two Epigravettian individuals was mainly based on terrestrial resources. But, while PA89 shows a high protein diet in line with Gravettians, with a scarce (or masked) intake of plant foods and a limited use of aquatic resource; PA85 retains a lighter nitrogen isotope fingerprint, suggesting a more balanced omnivorous diet with the consumption of both meat and plants. The likely higher consumption of low trophic level resources by PA85 matches the foraging model here proposed for the Epigravettians. Given the diverging Sr isotope ratios of fauna and humans, we infer that the Epigravettians from Grotta Paglicci exploited less intensively local macro-mammals. This, however, does not exclude the consumption of large game meat, but suggests the intake of non-local meat as seasonal or annual resource. Altogether, these evidences support a different mobility pattern between Epigravettians and Gravettians. Residential moves were the main system to tackle resources for Epigravettians, similarly to modern foragers.

Another possible explanation for the recurring non-local values of Epigravettians can be found in birth seasonality. Among the !Kung forager tribe of the Kalahari desert, conceptions are concentrated between June and August, when the highest amount of food is available and the season allows the least expenditure of energy (56). Assuming that moves of the base-camp during the Epigravettian were on a seasonal basis, we can prudently put forward the hypothesis that the three children here studied were born non-locally, maybe during favorable seasons. As the climate got worse and/or food resources run out, the human group might have moved camp to Grotta Paglicci in search of new resources or better living conditions. Nevertheless, our inferences are constrained by the limited number of human specimens at our disposal from the Epigravettian layers.

\section{Change in mobility strategies driven by climate or culture?}


Although a gradual climatic change has been detected globally across the LGM (from GS3 to GS2; 57), local paleoclimate proxies do not record strong modifications of the environment at Grotta Paglicci during the transition between the Gravettian to the Early Epigravettian, within the time-span covered by the human specimens of this study (45) (58). A persistence of cold steppe vegetation indicates a predominance of at least seasonally dry conditions, although with short intervals of woodlands expansion. Moreover, micromammal remains suggest the start of a gradual climatic improvement at the onset of the Early Epigravettian, ending with a shift to Mediterranean climate during the late phases of the Epigravettian (32).

Given the likely lack of an evident local and regional environmental change at Grotta Paglicci, we cannot be certain that the climate has influenced the human mobility change recorded by our data. Nevertheless, the occurrence of phases with stands of open coniferous woodland developed in favourable areas of the landscape may have pushed human to change their mobility pattern to adapt to the new environmental conditions (51).

We thus cautiously propose that the different mobility patterns observed in the Gravettian-Epigravettian transition of Paglicci might be related to cultural factors, which in turn may be indicative of a population replacement during the Epigravettian. This hypothesis agrees with genetic data $(13,14)$ and with the likely change in hunting strategies as testified by the lithic and bone industries of Grotta Paglicci (59). In particular, we observe a marked difference at the transition between the two technocomplexes in the lithic industry, with a substantial size increase during the Epigravettian, and a concurrent disappearance of the small curved points, typical of the Paglicci final Gravettian (59). Moreover, during the Early Epigravettian, a change in the hunting strategies is also reflected by the strong presence of antler spearpoints and shouldered stone points, correlated with a faunal assemblage mostly dominated by C. ibex remains (60). A population discontinuity hypothesis at the onset of the LGM was also put forward by (61), based on the analysis of cranial morphology. Here the authors found a strong statistical separation between pre-LGM and later human groups, suggesting population dynamics as the main cause of this divergent pattern.

Finally, we speculate that the global climate improvement might have facilitated the arrival of new groups of people from the North or East pushed by the general environment amelioration and the opening of new corridors.

\section{Methods}

Detailed methodological protocols are reported within the Supplementary Information. 
Fourteen human deciduous teeth (six incisors, two canines and six molars, see Table 2) from Grotta Paglicci were considered in this study (Fig. S6). Specimens PA92, PA93 and PA94 were recovered from the same archaeological layer (20d) and could have belong to the same individual. Similarly, also PA111 and PA112 come from the same archaeological layer (21c) (see the Supplementary Information for more details, Table S5). The ${ }^{87} \mathrm{Sr} /{ }^{86} \mathrm{Sr}$ ratios of all the teeth was measured in situ with a double focusing MC-ICP-MS Neptune ${ }^{\mathrm{TM}}$ (Thermo Fisher Scientific) coupled to a $213 \mathrm{~nm} \mathrm{Nd:YAG} \mathrm{laser} \mathrm{ablation} \mathrm{system} \mathrm{(New} \mathrm{Wave} \mathrm{Research}{ }^{\mathrm{TM}}$ ) housed at the Centro Interdipartimentale Grandi Strumenti (CIGS) of the University of Modena and Reggio Emilia, following protocols described in Lugli et al. (36). Rodent $(n=16)$ and macro-mammal $(n=69)$ teeth were collected from the layers of Grotta Paglicci, according to the chronological distribution of human samples. Modern plants were sampled in the area surrounding Grotta Paglicci and each specimen is a pool of different arboreal plants, grown in natural areas away from roads and cultivated fields (Table S2). Fauna and plant specimens were analyzed by solution MC-ICP-MS, after the chemical separation of Sr (30).

\section{Carbon and nitrogen stable isotopes of bone collagen}

The bone pretreatment method used on the two Gravettian individuals (PA12 and PA25) is the one established by (62; see Supplementary Information for details). The isotope analyses were conducted at the Max Planck Institute for Evolutionary Anthropology in Leipzig on a Thermo Finnigan Delta V Advantage Isotope Ratio Mass Spectrometer (IRMS) coupled to a Flash 2000 EA. The ulna Paglicci 12 (S-EVA 28202) and the rib of Paglicci 25 (S-EVA 13777) have extracts compatible with well-preserved collagen (63).

Bone collagen of the Epigravettian human specimens (PA85 and PA89) was extracted at the Stable Isotope Laboratory of the University of Parma, following the protocol described in $(64)$ and modified by $(65,66)$. Carbon and nitrogen ratios were measured by means of a $\mathrm{CHN}$ elemental analyzer coupled with a mass spectrometer.

Data availability

All data generated or analysed during this study are included in this paper (and its Supplementary Information files).

\section{Acknowledgments}

This project was funded by the European Research Council (ERC) under the European Union's Horizon 2020 Research and Innovation Programme (grant agreement No 724046 - SUCCESS awarded to Prof. Stefano Benazzi - erc-success.eu). The Radiogenic Isotope Laboratory of the University of Modena and Reggio Emilia has been funded through a grant of the Programma Giovani Ricercatori Rita Levi Montalcini (to Anna Cipriani). We thank the Soprintendenza Archeologia, Belle Arti e Paesaggio per le Province di Barletta-Andria-Trani e Foggia for supporting researches at Grotta Paglicci and prof. A. Palma di Cesnola for his scientific rigour in carrying out studies at Grotta Paglicci. The authors acknowledge prof. S. Conti for providing geological maps of the Apulia region.

\section{Author contribution}


F.L., A.C. and S.B. conceived the study and designed the experiments. F.L. and A.C. performed the laboratory work and the $\mathrm{Sr}$ isotope analyses. M.A.M, S.T., P.I. and M.P.R. designed and performed the stable isotope analyses. G.C., S.R., F.Bo, P.B. and A.R. provided the samples. F.Ba., F.Bo. and P.B. review palaeoclimate data. S.B., A.C. and A.R. supervised the work. All authors contributed to writing the manuscript.

\section{Competing interests}

The authors declare no competing interests.

\section{References}

1. Kelly RL (1992) Mobility/Sedentism: Concepts, Archaeological Measures, and Effects. Annu Rev Anthropol 21:43-66.

2. Hunter LM (2005) Migration and Environmental Hazards. Popul adn Environ 26:273-302.

3. Büntgen U, et al. (2011) 2500 Years of European Climate Variability and Human Susceptibility. Science (80- ) 331:578-583.

4. Kelley CP, Mohtadi S, Cane MA, Seager R, Kushnir Y (2015) Climate change in the Fertile Crescent and implications of the recent Syrian drought. Proc Natl Acad Sci 112: 3241-3246.

5. Tallavaara M, Luoto $M$, Korhonen N, Järvinen H, Seppä H (2015) Human population dynamics in Europe over the Last Glacial Maximum. Proc Natl Acad Sci 112:8232-8237.

6. Lamb HF, et al. (2018) 150,000-year palaeoclimate record from northern Ethiopia supports early, multiple dispersals of modern humans from Africa. Sci Rep 8:1077.

7. Halsall G (2007) Barbarian migrations and the Roman West, 376-568. Cambridge University Press.

8. Kuhn SL, Raichlen DA, Clark AMYE (2016) What Moves Us? How Mobility and Movement Are at the Center of Human Evolution. Evol Anthropol 25:86-97.

9. D'Andrea WJ, Huang Y, Fritz SC, Anderson NJ (2011) Abrupt Holocene climate change as an important factor for human migration in West Greenland. Proc Natl Acad Sci 108:9765-9769. 
10. Timmermann A, Friedrich T (2016) Late Pleistocene climate drivers of early human migration. Nature 538: 92-95.

11. Venkataraman VV, Kraft TS, Dominy NJ, Endicott KM (2017) Hunter-gatherer residential mobility and the marginal value of rainforest patches. Proc Natl Acad Sci 114:3097-3102.

12. Binford LR (1980) Willow Smoke and Dogs' Tails: Hunter-Gatherer Settlement Systems and Archaeological Site Formation. Am Antiq 45:4-20.

13. Pala M, et al. (2012) Mitochondrial DNA signals of late glacial recolonization of Europe from near eastern refugia. Am J Hum Genet 90:915-924.

14. Fu Q, et al. (2016) The genetic history of Ice Age Europe. Nature 534:200-205.

15. Arrizabalaga A, Calvo A, Elorrieta I, Tapia J, Tarriño A (2014) Where to and what for? Mobility patterns and the management of lithic resources by Gravettian hunter-gatherers in the Western Pyrenees. J Anthropol Res 70: 233-261.

16. Aranguren B, et al. (2015) Territorial exploitation in the Tyrrhenian Gravettian Italy: The case-study of Bilancino (Tuscany). Quat Int 359-360:442-451.

17. Moreau L, et al. (2016) Geochemical Sourcing of Flint Artifacts from Western Belgium and the German Rhineland: Testing Hypotheses on Gravettian Period Mobility and Raw Material Economy. Geoarchaeology An Int J 31:229-243.

18. Tomasso A, Porraz G (2016) Hunter-gatherer mobility and embedded raw-material procurement strategies in the mediterranean upper paleolithic. Evol Anthropol 25:164-74.

19. Holt BM (2003) Mobility in Upper Paleolithic and Mesolithic Europe: evidence from the lower limb. Am J Phys Anthropol 122: 200-215.

20. Villotte S, Samsel M, Sparacello V (2017) The paleobiology of two adult skeletons from Baousso da Torre (Bausu da Ture)(Liguria, Italy): Implications for Gravettian lifestyle. Comptes Rendus Palevol, $16: 462-473$.

21. Villotte S, Churchill SE, Dutour OJ, Henry-Gambier D (2010) Subsistence activities and the sexual division of labor in the European Upper Paleolithic and Mesolithic: evidence from upper limb enthesopathies. J Hum Evol, 59:35-43. 
22. Holt BM, Formicola V (2008) Hunters of the Ice Age: The biology of Upper Paleolithic people. Am J Phys Anthropol 137 (S47):70-99.

23. Boscato $P$ (2007) Faunes gravettiennes à grands mammifères de l'Italie du Sud: Grotta della Cala (Salerno) et Grotta Paglicci (Foggia). PALEO. Revue d'archéologie préhistorique 19:109-114.

24. Tagliacozzo A, Zeppieri F, Fiore I, Spinapolice E, Del Lucchese A (2012) Archaeozoological evidence of subsistence strategies during the Gravettian at Riparo Mochi (Balzi Rossi, Ventimiglia, Imperia - Italy). Quat Int 252:142-154.

25. Bentley RA (2006) Strontium isotopes from the earth to the archaeological skeleton: a review. Journal of Archaeological Method and Theory 13:135-187.

26. Richards M, et al. (2008) Strontium isotope evidence of Neanderthal mobility at the site of Lakonis, Greece using laser-ablation PIMMS. J Archaeol Sci 35:1251-1256.

27. Willmes M, et al. (2016) Improvement of laser ablation in situ micro-analysis to identify diagenetic alteration and measure strontium isotope ratios in fossil human teeth. J Archaeol Sci 70:102-116.

28. Copeland SR, et al. (2011) Strontium isotope evidence for landscape use by early hominins. Nature 474:76-78.

29. Balter V, Braga J, Télouk P, Thackeray J F (2012) Evidence for dietary change but not landscape use in South African early hominins. Nature 489:558-560.

30. Lugli F, Cipriani A, Arnaud J, Arzarello M, Peretto C, Benazzi S (2017) Suspected limited mobility of a Middle Pleistocene woman from Southern Italy: strontium isotopes of a human deciduous tooth. Sci Rep 7:8615.

31. Ronchitelli A, et al. (2015) When technology joins symbolic behaviour : The Gravettian burials at Grotta Paglicci (Rignano Garganico e Foggia e Southern Italy). Quat Int 359:423-441.

32. Berto C, Boscato P, Boschin F, Luzi E, Ronchitelli A (2017) Paleoenvironmental and paleoclimatic context during the Upper Palaeolithic (late Upper Pleistocene) in the Italian Peninsula. The small mammal record from Grotta Paglicci (Rignano Garganico, Foggia, Southern Italy). Quat Sci Rev 168:3041. 
33. Sommer RS, Nadachowski A (2006) Glacial refugia of mammals in Europe: evidence from fossil records. Mammal Rev 36:251-265.

34. lacumin P, Bocherens $H$, Huertas AD, Mariotti A, Longinelli A (1997) A stable isotope study of fossil mammal remains from the Paglicci cave, Southern Italy: $\mathrm{N}$ and $\mathrm{C}$ as palaeoenvironmental indicators. Earth Planet Sci Lett 148:349-357.

35. Pellegrini M, et al. (2008) Faunal migration in late-glacial central Italy: implications for human resource exploitation. Rapid Commun Mass Spectrom 22:1714-1726.

36. Lugli F, Cipriani A, Peretto C, Mazzucchelli M, Brunelli D (2017) In situ high spatial resolution 87Sr/86Sr ratio determination of two Middle Pleistocene (ca $580 \mathrm{ka}$ ) Stephanorhinus hundsheimensis teeth by LA-MC-ICP-MS. Int J Mass Spectrom 412:38-48.

37. Emery M V, et al. (2018) Mapping the origins of Imperial Roman workers (1st-4th century CE) at Vagnari, Southern Italy, using $87 \mathrm{Sr} / 86 \mathrm{Sr}$ and d180 variability. Am J Phys Anthropol. doi:10.1002/ajpa.23473.

38. De Astis G, Kempton PD, Peccerillo A, Wu TW (2006) Trace element and isotopic variations from Mt. Vulture to Campanian volcanoes: constraints for slab detachment and mantle inflow beneath southern Italy. Contributions Mineral Petrol 151:331-351

39. Schlüter M, Steuber T, Parente M (2008) Chronostratigraphy of Campanian-Maastrichtian platform carbonates and rudist associations of Salento (Apulia, Italy). Cretac Res 29:100-114.

40. Zampella M, et al. (2011) Soil properties, strontium isotopic signatures and multi-element profiles to authenticate the origin of vegetables from small-scale regions: illustration with early potatoes from southern Italy. Rapid Comm Mass Spectrom 25: 2721-2731.

41. Vukosavljević N, Perhoč Z (2017). Lithic raw material procurement of the Late Epigravettian huntergatherers from Kopačina Cave (island of Brač, Dalmatia, Croatia). Quat Int 450:164-185.

42. Montgomery J, Evans JA, Cooper RE (2007) Resolving archaeological populations with Sr-isotope mixing models. Appl Geochemistry 22:1502-1514.

43. Frei KM, Price TD (2012) Strontium isotopes and human mobility in prehistoric Denmark. Archaeol Anthropol Sci 4:103-114. 
44. Binford LR (1978) Dimensional analysis of behavior and site structure: learning from an Eskimo hunting stand. Am Antiq 43:330-361.

45. Boschin F, Boscato P, Berto C, Crezzini J, Ronchitelli A (2018) The palaeoecological meaning of macromammal remains from archaeological sites exemplified by the case study of Grotta Paglicci (Upper Palaeolithic, Southern Italy). Quat Res 90, 470-482.

46. Richards, M. P., Jacobi, R. M., Cook, J., Pettitt, P. B., \& Stringer, C. B. (2005). Isotope evidence for the intensive use of marine foods by Late Upper Palaeolithic humans. Journal of Human Evolution, 49(3), 390-394.

47. Richards MP (2009) Stable isotope evidence for European Upper Paleolithic human diets. In: Hublin JJ and Richards MP (ed.), «The Evolution of Hominin Diets», Springer, Dordrecht, pp. 251-257.

48. Richards MP, Trinkaus E (2009) Isotopic evidence for the diets of European Neanderthals and early modern humans. Proc Natl Acad Sci 106:16034-16039.

49. Tagliacozzo A, Gala M (2004) L'avifauna dei livelli 24-22 (Aurignaziano e Gravettiano antico) di Grotta Paglicci: I'aspetto ambientale e quello economico. Paglicci, I'Aurignaziano e il Gravettiano antico, ed. Di Cesnola P, (Grenzi, Foggia), pp 71-89.

50. Mariotti Lippi M, Foggi B, Aranguren B, Ronchitelli A, Revedin A (2015) Multistep food plant processing at Grotta Paglicci (Southern Italy) around 32,600 cal BP. Proc Natl Acad Sci 112:12075-12080.

51. Kelly RL (2007) The Foraging Spectrum: Diversity in Hunter-Gatherer Lifeways. Percheron Press.

52. Wall-Scheffler CM, Myers MJ (2013) Reproductive costs for everyone: how female loads impact human mobility strategies. J Hum Evol 64:448-456.

53. Colonese AC, Mannino MA, Mayer DBY, Fa DA, Finlayson JC, Lubell D, Stiner MC (2011). Marine mollusC exploitation in Mediterranean prehistory: an overview. Quat Int 239:86-103.

54. Milliken S (1998) Hunter-gatherer land use in Late Glacial south-east Italy. Oxford Journal of Archaeology 17:269-286.

55. Riel-Salvatore J, Barton CM (2004) Late Pleistocene technology, economic behavior, and land-use dynamics in southern Italy. Am Antiq 69:257-274. 
56. Bentley GR (1985) Hunter-Gatherer Energetics and Fertility: A Reassessment of the !Kung San. Hum Ecol 13:79-107.

57. Andersen KK, et al. (2006) The Greenland Ice Core Chronology 2005 , 15-42 ka. Part 1 : constructing the time scale. Quat Sci Rev 25:3246-3257.

58. Allen JR, et al. (1999) Rapid environmental changes in southern Europe during the last glacial period. Nature 400:740-743.

59. Bartolomei G, Broglio A, Palma di Cesnola A (1979) Chronostratigraphie et écologie de l'Épigravettien en Italie, in: de Sonneville-Bordes D. (ed.), «La Fin des Temps Glaciaires en Europe», Ed. du CNRS, Paris, pp. 297-324.

60. Borgia V, Boschin F, Ronchitelli A (2016) Bone and antler working at Grotta Paglicci (Rignano Garganico, Foggia, Southern Italy). Quat Int 403:23-39.

61. Brewster C, Meiklejohn C, von Cramon-Taubadel N, Pinhasi R. (2014) Craniometric analysis of European Upper Palaeolithic and Mesolithic samples supports discontinuity at the Last Glacial Maximum. Nature Comm 5:4094.

62. Talamo S, Richards MA (2011) Comparison of Bone Pretreatment Methods for AMS Dating of Samples $>30,000$ BP. Radiocarbon 53:443-449.

63. Van Klinken GJ (1999) Bone collagen quality indicators for palaeodietary and radiocarbon measurements. J Archaeol Sci 26:687-695.

64. Longin R (1971) New method of collagen extraction for radiocarbon dating. Nature 230:241-242.

65. Ambrose SH (1990) Preparation and characterization of bone and tooth collagen for isotopic analysis. J Archaeol Sci 17:431-451.

66. Bocherens $\mathrm{H}$, et al. (1991) Isotopic biogeochemistry (13C, 15N) of fossil vertebrate collagen: implications for the study of fossil food web including Neandertal Man. J Hum Evol 20:481-492.

67. Nelson SJ, Ash MM (2010) Wheeler's Dental Anatomy, Physiology, and Occlusion, 9th Edition (Saunders/Elsevier).

68. Tafuri MA, et al. (2016) Life and Death in Neolithic Southeastern Italy: The Strontium Isotopic Evidence. Int J Osteoarchaeol 26:1045-1057. 


\begin{tabular}{|c|c|c|c|c|c|c|}
\hline Sample & Species & $\begin{array}{l}\text { Average } \\
{ }^{87} \mathrm{Sr} /{ }^{86} \mathrm{Sr}\end{array}$ & $2 \sigma$ & $\begin{array}{c}\text { Max } \\
{ }^{87} \mathrm{Sr} /{ }^{86} \mathrm{Sr}\end{array}$ & $\underset{{ }^{87} \mathrm{Sr} /{ }^{86} \mathrm{Sr}}{\operatorname{Min}}$ & $n$ \\
\hline \multirow{3}{*}{ Macro-mammals } & Equus ferus & 0.70854 & 0.00028 & 0.70868 & 0.70813 & 30 \\
\hline & Equus hydruntinus & 0.70861 & 0.00025 & 0.70881 & 0.70842 & 10 \\
\hline & Capra ibex & 0.70856 & 0.00014 & 0.70863 & 0.70831 & 29 \\
\hline Rodents & Microtinae indet. & 0.70842 & 0.00016 & 0.70857 & 0.70826 & 16 \\
\hline Modern plants & n.d. & 0.70846 & 0.00043 & 0.70898 & 0.70813 & 27 \\
\hline
\end{tabular}

Table 2. Strontium isotope data of human deciduous teeth from Grotta Paglicci.

\begin{tabular}{|c|c|c|c|c|c|c|c|c|c|}
\hline Technocomplex & Layer & Sample & $\begin{array}{l}\text { Tooth } \\
\text { element }\end{array}$ & $\begin{array}{c}\text { Crown } \\
\text { formation } \\
\text { (months) }\end{array}$ & ${ }^{88} \mathrm{Sr}(\mathrm{V})$ & $\begin{array}{l}\text { Avg. } \\
{ }^{87} \mathrm{Sr} /{ }^{86} \mathrm{Sr}\end{array}$ & $2 \sigma$ & $\begin{array}{l}\text { Analyses } \\
\text { per tooth }\end{array}$ & $\begin{array}{c}\text { Avg. } \\
{ }^{87} \mathrm{Sr} / /^{86} \mathrm{Sr} \text { of } \\
\text { the period }^{+\dagger}\end{array}$ \\
\hline \multirow{3}{*}{$\begin{array}{c}\text { Early } \\
\text { Epigravettian }\end{array}$} & $12 f$ & PA82 & $\operatorname{Ldi}^{2}$ & -5 to 2.5 & 0.53 & 0.70930 & 0.00028 & 3 & \multirow{3}{*}{0.70926} \\
\hline & 14 & PA83 & $\operatorname{Ldi}^{2}$ & -5 to 2.5 & 0.58 & 0.70928 & 0.00032 & 4 & \\
\hline & $16 a$ & PA87 & $\mathrm{Rdm}^{1}$ & -5 to 6 & 0.65 & 0.70921 & 0.00041 & 3 & \\
\hline \multirow{2}{*}{ Final Gravettian } & $18 \mathrm{~b}$ & PA90 & di(?) & -5 to 2 & 0.54 & 0.70859 & 0.00070 & 2 & \multirow{2}{*}{0.70890} \\
\hline & $19 a$ & PA91 & $\mathrm{Rdm}^{1}$ & -5 to 6 & 1.01 & 0.70900 & 0.00056 & 6 & \\
\hline \multirow{7}{*}{$\begin{array}{l}\text { Evolved } \\
\text { Gravettian }\end{array}$} & $20 d$ & PA92 & $\mathrm{Rdm}^{1}$ & -5 to 6 & 0.53 & 0.70852 & 0.00106 & 2 & \multirow{7}{*}{0.70847} \\
\hline & $20 d$ & PA93 & $\mathrm{Rdm}_{1}$ & -5 to 5.5 & 0.58 & 0.70839 & 0.00088 & 6 & \\
\hline & $20 d$ & PA94 & $\mathrm{Ldm}_{1}$ & -5 to 5.5 & 0.89 & 0.70880 & 0.00111 & 7 & \\
\hline & $20 \mathrm{e}$ & PA95 & $d i^{1}$ & -5.5 to 1.5 & 0.66 & 0.70845 & 0.00100 & 4 & \\
\hline & $21 c$ & PA111 & Ldi $^{1}$ & -5.5 to 1.5 & 0.72 & 0.70845 & 0.00027 & 5 & \\
\hline & $21 c$ & PA112 & $\mathrm{Ldc}_{*}$ & -5 to 9 & 0.53 & 0.70812 & 0.00053 & 4 & \\
\hline & $21 d$ & PA40 & $\mathrm{Rdm}_{2}$ & -4.5 to 10 & 0.55 & 0.70835 & 0.00036 & 4 & \\
\hline \multirow{2}{*}{ Early Gravettian } & $22 \mathrm{e}$ & PA129 & $\mathrm{Ldc}^{*}$ & -5 to 9 & 0.67 & 0.70800 & 0.00089 & 4 & \multirow{2}{*}{0.70808} \\
\hline & $23 a$ & PA130 & $\operatorname{Ldi}_{1}$ & -5.5 to 2.5 & 0.60 & 0.70813 & 0.00077 & 7 & \\
\hline
\end{tabular}

The approximate crown formation timings are from (68). ${ }^{\dagger} \mathrm{L}$ or $\mathrm{R}$ means left or right respectively; di, $\mathrm{dc}$ and dm mean deciduous incisor, canine, and molar, respectively; the number and its position (superscript/subscript) indicate the tooth class and upper/lower, respectively (e.g. $\mathrm{Rdm}^{1}$ is the deciduous right upper first molar); * its position (superscript or subscript) indicates upper or lower, respectively. ${ }^{++}$Mean Sr isotope values for the different periods are calculated from the single LA microsamples reported in Table S4. 


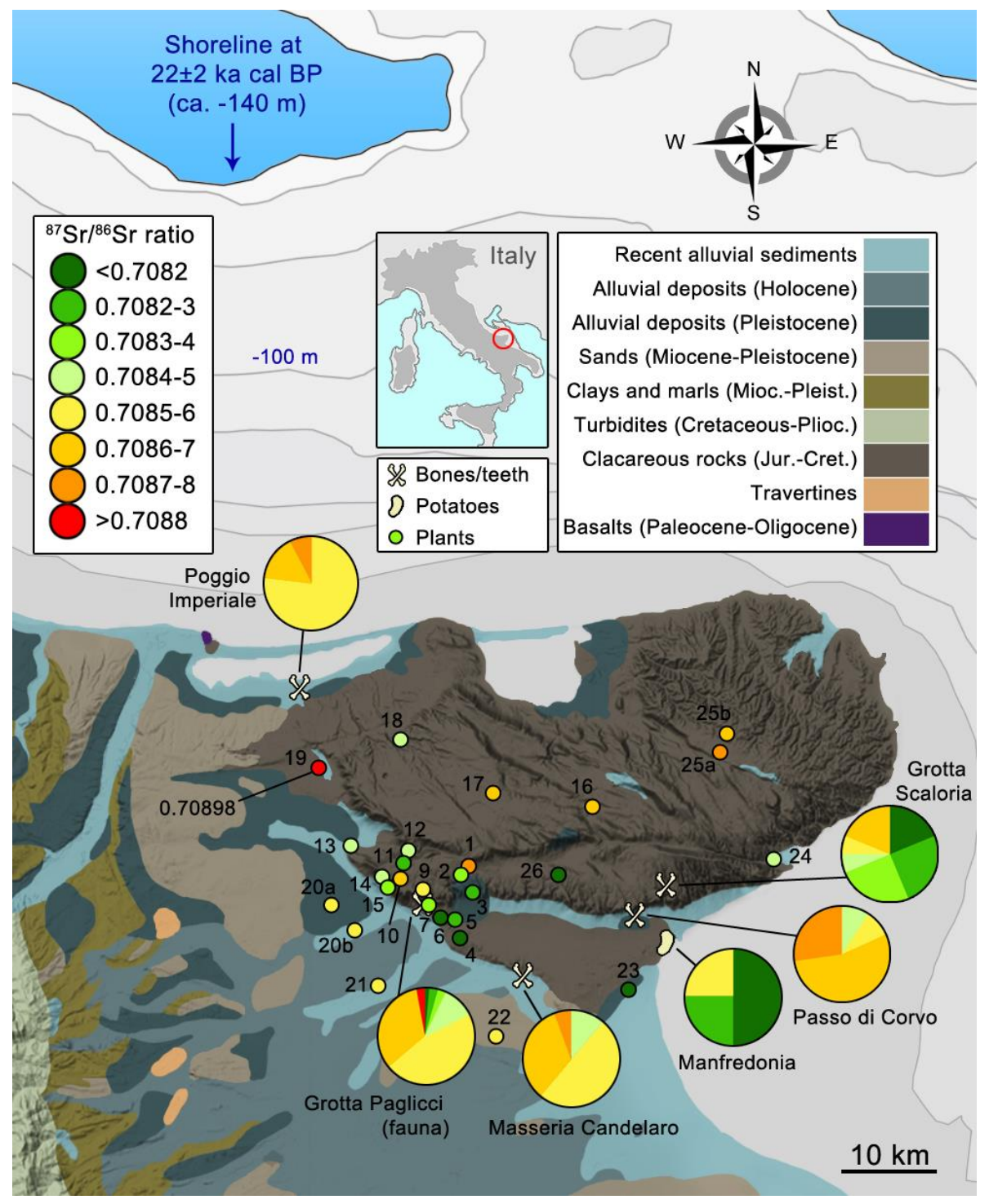

Figure 1. Simplified geological map of the surroundings of Grotta Paglicci (location \#7). The location of the modern plant sampling sites are numbered and color coded based on the average Sr isotope ratio of the plants. Pie charts indicate the different proportion of Sr isotope ratios of plants and bone/tooth samples from a specific site. The pie chart Grotta Paglicci depicts the Sr isotope proportion of the fauna enamel samples. Poggio Imperiale, Grotta Scaloria, Passo di Corvo and Masseria Candelaro sites include bone and tooth Sr isotope ratios from (69). Manfredonia site include potatoes data from (40). 


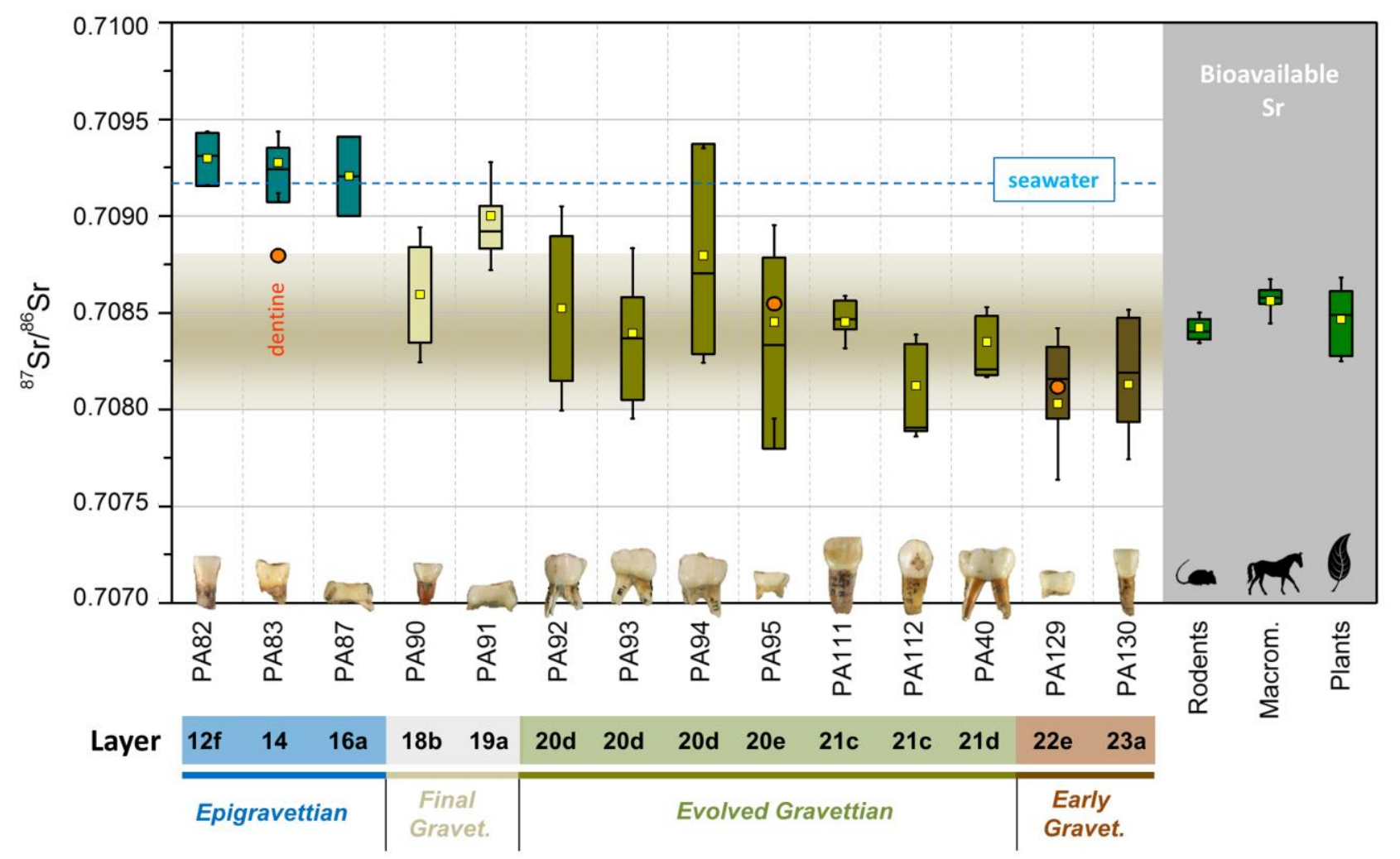

Figure 2. Sr isotope ratios of human deciduous teeth from Grotta Paglicci. Bioavailable Sr isotope ratios are reported for comparison. A cut-off value of 0.7088 is set as the maximum value for the local isotope baseline. Box plot bars are $1 \sigma$. 


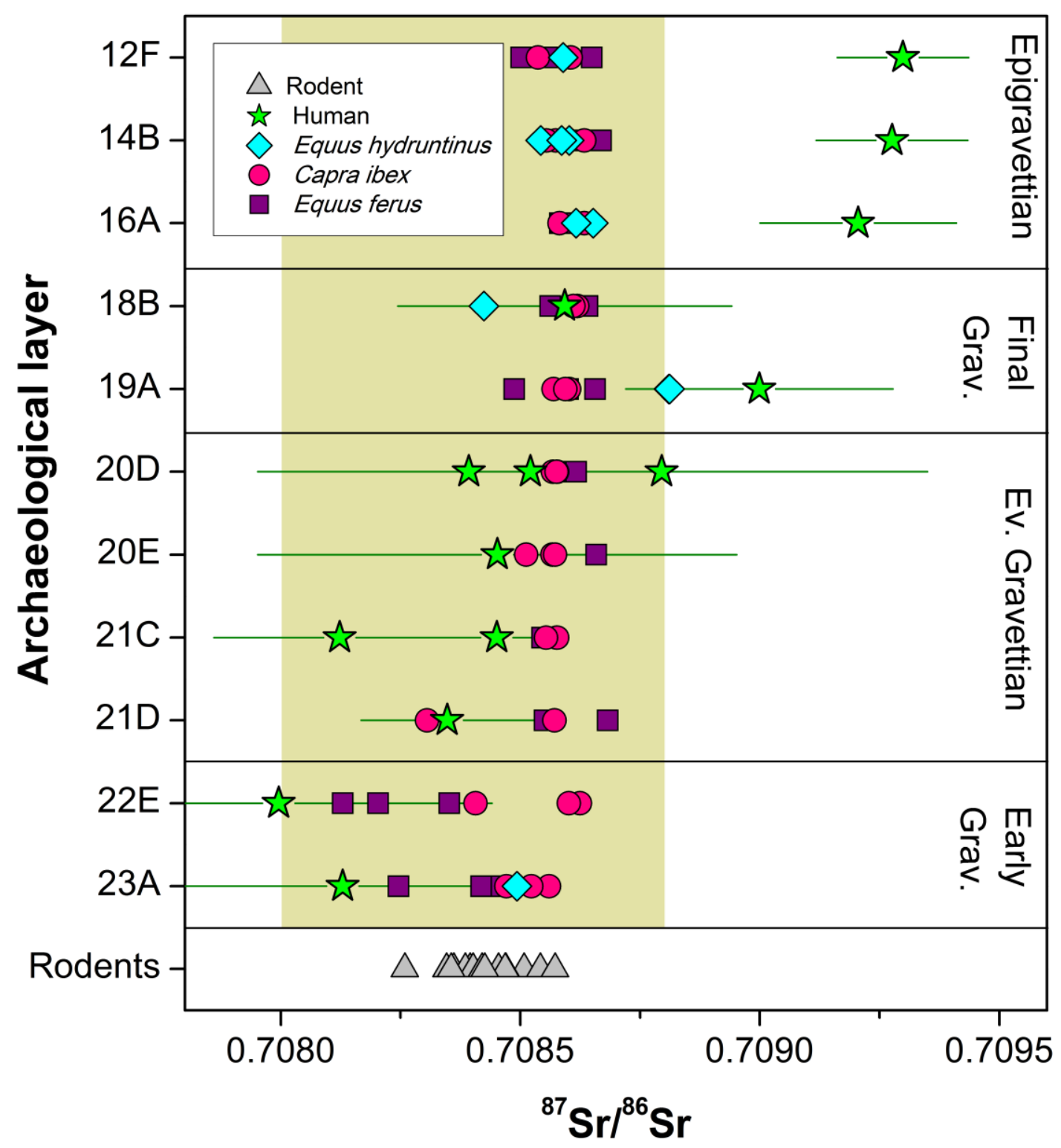

Figure 3. Sr isotope ratios of Grotta Paglicci human teeth with the relative stratigraphic position. Mammals from each layer are also reported for comparison. The shaded area is the local Sr isotope range. Error bars are $1 \sigma$. 


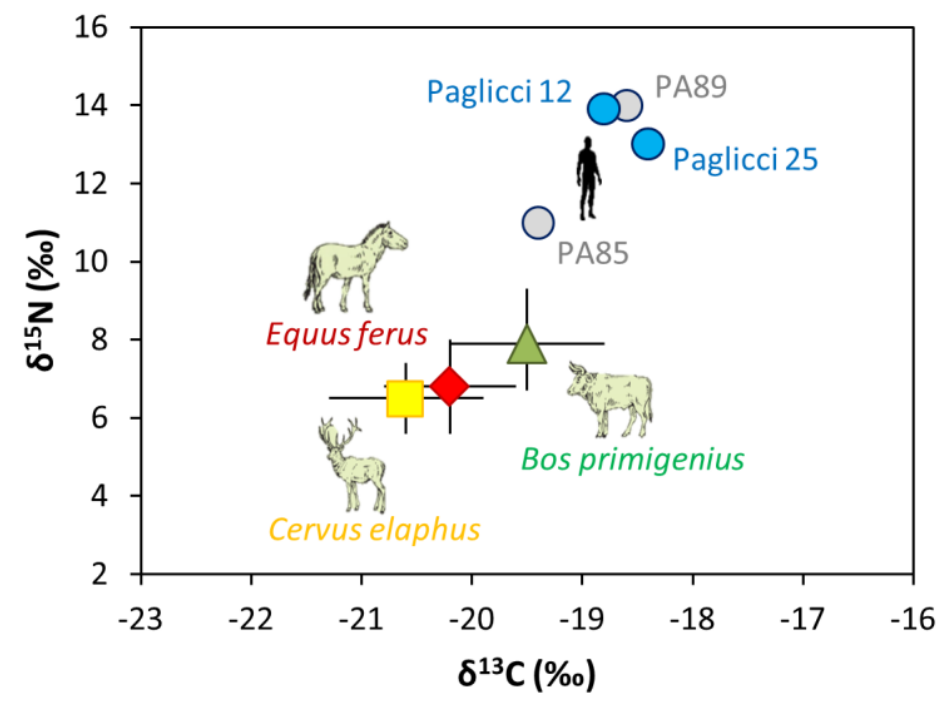

Figure 4. Bone collagen $\mathrm{N}$ and $\mathrm{C}$ stable isotopes of four humans from Grotta Paglicci (full circles). PA85 and PA89 are Epigravettians; Paglicci 12 and Paglicci 25 are Gravettians. Fauna samples (different symbols color coded with the relative specific name in the figure) are mean values $\pm 1 \sigma$ from (34). The summary statistics for the three main macro-mammals species throughout the Paglicci sequence are as follows: Cervus elaphus $\left(\delta^{13} \mathrm{C}\right.$ : range $=-22.4 \%$ o to $-19.8 \%$, mean $=-20.6 \pm 0.7 \%$; $\delta^{15} \mathrm{~N}$ : range $=5.0 \%$ o to $8.5 \%$, mean $=6.5 \pm$ $0.9 \%$ ), Bos primigenius $\left(\delta^{13} \mathrm{C}\right.$ : range $=-20.9 \%$ o to $-17.8 \%$, mean $=-19.5 \pm 0.7 \%$; $\delta^{15} \mathrm{~N}$ : range $=6.1 \%$ o to $11.9 \%$, mean $=7.9 \pm 1.4 \%$ o and Equus ferus ( $\delta^{13} \mathrm{C}$ : range $=-21.3 \%$ o to $-19.1 \%$, mean $=-20.2 \pm 0.6 \% ; \delta^{15} \mathrm{~N}$ : range $=4.3 \%$ o to $8.4 \%$, mean $=6.8 \pm 1.2 \%$ o). 